\title{
Incidence of Insect Pests and Natural Enemies in Sunflower Crop Ecosystem
}

\author{
S. Geetha* and M.G. Hegde \\ Department of Agriculture Entomology, College of Agriculture, Dharwad, UAS, \\ Dharwad-580005, Karnataka, India \\ *Corresponding author
}

\section{A B S T R A C T}

Keywords

Insect pest, Incidence,

Correlation,

Sunflower

\section{Article Info}

Accepted:

10 August 2018

Available Online:

10 September 2018
The incidence of insect pests and natural enemy population was studied at Main Agricultural Research Station (MARS), Dharwad, University of Agricultural sciences, Dharwad. In sunflower ecosystem 14 insects pest and 10 natural enemies (Predators) were recorded during the study. The Amrasca biguttula biguttula (Ishida) population was higher during vegetative to reproductive stage of the crop and peaked at $43^{\text {rd }}$ and $46^{\text {th }} \mathrm{SMW}$ respectively, during 2015 and 2016. There was a significant and positive correlation between leafhopper population and maximum temperature. The correlation with all the other weather parameters was significant and negative. The incidence of Spilarctia obliqua (Walker) attained a peak at $42^{\text {nd }}$ SMW during both 2015 and 2016. The correlation between their population and weather parameters was found to be non-significant during both the seasons (2015 \& 2016). The predatory population prevailed throughout the cropping period during both the seasons. The mean predatory population was highest in $42^{\text {nd }}$ SMW and $46^{\text {th }}$ SMW during 2015. However, their maximum incidence was recorded during $40^{\text {th }}$ SMW and $42^{\text {nd }}$ SMW during 2016.

\section{Introduction}

Sunflower (Helianthus annuus L.) is an annual plant, which is native of America. It belongs to the Family: Asteraceae (Compositae), Genus: Helianthus, Species: annuus. Sunflower oil is generally considered as premium oil due its light colour, high level of unsaturated fatty acids, lack of linolenic acid and bland flavor and oil content in seed ranges from 39 to 49 per cent in commercially available cultivers. In India, during 2015-16, the area under sunflower cultivation was 0.48 million ha, with a total annual production of 0.29 million tonnes (India stat.com) and productivity of $608 \mathrm{~kg}$ per ha. The sunflower cultivation is largely confined to south Indian peninsular states viz., Karnataka, Andhra Pradesh, Maharashtra and Tamil Nadu, among which Karnataka occupies first position accounting for an area of 0.33 million ha with a production of 0.14 million tonnes and productivity of $418 \mathrm{~kg}$ per ha (India stat.com).

Karnataka state is popularly known as the "Sunflower State" of India, as the state accounts for more than 67.60 per cent of the total acreage and also has been contributing 
34.00 per cent of the national sunflower production. But of late, many abiotic and biotic stress factors have largely contributed to the decline in sunflower area in Karnataka, of which insect pests are having a prime role. The climatic scenario has been changing over the years across the world. The pest population and natural enemies on different crops including sunflower might have also changed accordingly. Conducting study on incidence of different insect pest and natural enemies may be the right research tool to investigate the existence of different insect pests, level of incidence at different stages of the crop during the growing season and their natural enemies abundance in sunflower ecosystem.

\section{Materials and Methods}

In order to study the incidence of insect pests and their natural enemies on sunflower, DFSH-3hybrid seeds were sown in plots of size $3.0 \mathrm{mx} 3.0 \mathrm{~m}$ in three replications on $28^{\text {th }}$ August, 2015 and $30^{\text {th }}$ August, 2016 at Main Agricultural Research Station (MARS), UAS, Dharwad. All the recommended agronomic practices, except plant protection, were followed as per Package of Practice of UAS, Dharwad. Observations were recorded on the incidence of mainly defoliators and also other insect pests on ten randomly selected plants in each plot with an interval of one week as follows:

Lepidopteron insect pests: Number of caterpillars/ plant

Coleopteran insect pests: Number of adult beetles / weevils/ per plant

Leafhopper, thrips and whitefly: Total number of nymphs and adults / six leaves /plant

(i.e., two leaves each from the bottom, middle and top position of the plant)
The data pertaining to seasonal incidence was subjected to correlation and multiple linear regression analysis with meteorological parameters such as, maximum temperature, minimum temperature, morning relative humidity, afternoon relative humidity, total rainfall and wind velocity. The weekly average of weather parameters were correlated with the insect population of corresponding week. In case of rainfall, the weekly total was considered instead of weekly average.

\section{Results and Discussion}

Incidence of sucking pests, defoliators and predators on sunflower was recorded with regular weekly intervals from $37^{\text {th }}$ to $46^{\text {th }}$ Standard Meteorological Weeks (SMW) during the crop growth period in 2015 and 2016. The insects pest and natural enemies recorded during course of evaluation was enlisted in Table 1 and 2. The findings are presented here under.

\section{Amrasca biguttula biguttula (Ishida)}

The incidence ranged from 2.00 to 22.30 per 6 leaves per plant and 0.30 to 8.70 per six leaves per plant in 2015 and 2016 respectively. The incidence appeared from $37^{\text {th }}$ SMW $(2.00 / 6$ leaves/ plant) and attained its peak of 22.30 per six leaves per plant at $43^{\text {rd }}$ SMW and decreased slowly to reach 18.50 per six leaves per plant in $46^{\text {th }}$ SMW during 2015. Similarly, the incidence appeared during $37^{\text {th }}$ SMW (0.50/6 leaves/plant) and their population remained low throughout the season to attain a peak of 8.70 per six leaves per plant at $46^{\text {th }}$ SMW in the year 2016. The pooled data indicated maximum and minimum population of 13.60 and 1.25 per six leaves per plant was respectively prevailed during $46^{\text {th }}$ and $37^{\text {th }}$ SMW (Table 3). There existed a significant and positive correlation between A. biguttula biguttulas population and maximum temperature $\left(r=0.65^{*}\right)$ in 2015. However, 
correlation between A. biguttula biguttula and all the other weather parameters \{minimum temperature $\left(\mathrm{r}=-0.81^{* *}\right)$, morning relative humidity $\left(\mathrm{r}=-0.77^{* *}\right)$, evening relative humidity $\left(\mathrm{r}=-0.74^{*}\right)$ and wind velocity ($\left.\left.0.68^{*}\right)\right\}$ except rainfall $(\mathrm{r}=-0.29)$ showed significant negative correlation. The correlation of A. biguttula biguttula with weather parameters was non-significant during 2016. The pooled data indicated significant and positive correlation with maximum temperature $\left(\mathrm{r}=0.83^{* * *}\right)$ and it was significant and negative with remaining parameters except rainfall $(\mathrm{r}=-0.37)$ where it was nonsignificant (Table 4). The multiple linear regression equation was fitted for both 2015 and 2016 separately and also for the pooled data. The multiple linear regression equation of pooled data $\mathrm{Y}=-2.816+1.355 \mathrm{X}_{1}-1.487 \mathrm{X}_{2}-$ $0.037 \mathrm{X}_{3}+0.082 \mathrm{X}_{4}-0.011 \mathrm{X}_{5}-0.057 \mathrm{X}_{6}$ indicated one unit increase in minimum temperature, morning relative humidity, rainfall and wind velocity caused increase A. biguttula biguttula population by $1.487,0.037,0.011$ and 0.0577 units. However, a unit increase in maximum temperature and evening relative humidity caused decrease in their population by 1.355 and 0.082 units. The weather factors collectively influenced the population of $A$. biguttula biguttulas to the extent of 92.0 per cent (Table 5). Comparatively higher population of A. biguttula biguttula during 2015 might be due to prevailed favorable dry weather with moderate temperature. However, during 2016, there was intermittent rain might have created comparatively wet weather which may not favorable for their population buildup.

The finding of Men et al., (1996) is in line with the present study and who reported the higher population of leafhopper (A. bigutella bigutella) at 34-81 days after sowing of sunflower. They further reported a significant positive correlation between pest abundance and maximum temperature. Whereas, significant negative correlation was recorded with minimum temperature, relative humidity in the morning and evening. Similarly Meenakshi (2006) reported a positive correlation with the maximum temperature and negative correlation with relative humidity at Bengaluru, on sunflower. The peak population of leafhopper was recorded at $37^{\text {th }}$ MSW at Akola and a higher population was prevailed from the middle of November to till the end of December in Raichur (Anon., 2002). Most of the earlier findings support the present investigation and little variation could be due to the local acclimatization of the leafhoppers across the geographical area.

\section{Bamisia tabaci (Gennadius)}

Population during 2015 ranged from 0.50 to 1.70 per six leaves per plant. The incidence appeared from $37^{\text {th }}$ SMW with a peak incidence of 1.40 per six leaves per plant and decrease later to reach 0.50 per six leaves per plant in $45^{\text {th }}$ SMW. In 2016, the incidence ranged from 0.00 to 2.60 per six leaves per plant and the incidence appeared from $37^{\text {th }}$ SMW (0.50/6 leaves/plant) and attains peak on $43^{\text {rd }}$ SMW (2.60/6 leaves/plant) and died down later to reach nil at $45^{\text {th }}$ SMW in 2016. The pooled data shows maximum and minimum incidence of 1.65 and 0.25 per six leaves per plant respectively during $43^{\text {rd }}$ and $45^{\text {th }}$ SMW (Table 3). The correlation of whiteflies population with weather parameters was non-significant in both the years 2015 and 2016 (Table 4). The multiple linear regression analysis indicates that all the weather factors put together influence the $B$. tabaci incidence to an extent of 72.6 and 91.2 per cent respectively in 2015 and 2016. The pooled analysis indicated a non-significant correlation with weather parameters. The multiple linear regression equation of pooled data $\mathrm{Y}=-2.199$ $0.025 \mathrm{X}_{1}+0.487 \mathrm{X}_{2}-0.057 \mathrm{X}_{3}-0.030 \mathrm{X}_{4}+$ $0.002 X_{5}+0.014 X_{6}$ indicated one unit increase in maximum temperature, morning relative 
humidity, evening relative humidity caused increase $B$. tabaci population by $0.025,0.057$ and 0.030 units. However, a unit increase in minimum temperature, rainfall and wind velocity caused decrease in their population by $0.487,0.002$ and 0.014 units. The weather factors collectively influenced the population of $B$. tabaci to the extent of 88.6 per cent (Table 5).

\section{Thrips}

Population was very low in both the years and which ranged from 0.00 to 1.00 and 0.00 to 1.90 per six leaves per plant during 2015 and 2016, respectively. The incidence appeared from $37^{\text {th }}$ SMW both during 2015 and 2016 (0.60 and $0.70 / 6$ leaves/plant respectively) and highest incidence of 1.00 per six leaves per plant was recorded in $38^{\text {th }}$ SMW during 2015 and it was in $40^{\text {th }}$ SMW (1.90/6 leaves/plant) during 2016. The population later decreased to reach nil at $42^{\text {nd }}$ SMW onwards in both the years. Whereas, the pooled data indicated maximum incidence during $38^{\text {th }}$ SMW (1.10/ 6 leaves/ plant) (Table 3). In 2015, thrips population showed a significant and negative correlation with maximum temperature $(\mathrm{r}=$ $0.79^{* * *}$, whereas it was significant and positive with minimum temperature $\left(\mathrm{r}=0.66^{*}\right)$ and wind velocity $\left(\mathrm{r}=0.80^{\text {*** }}\right)$. In 2016, morning relative humidity $\left(\mathrm{r}=0.77^{* *}\right)$, evening relative humidity $\left(\mathrm{r}=0.85^{* *}\right)$ and wind velocity $(\mathrm{r}=$ $0.83^{* * *}$ ) showed highly significant and positive correlation with thrips population. However, maximum temperature $\left(\mathrm{r}=-0.81^{* *}\right)$ showed highly significant and negative correlation (Table 4). The multiple linear regression analysis indicates that all the weather factors put together influence the thrips incidence to an extent of 93.5 and 80.0 per cent respectively during 2015 and 2016. The pooled analysis indicated significant correlation and negative correlation with maximum temperature $\left(\mathrm{r}=-0.83^{* *}\right)$. However, the remaining parameters showed significant and positive correlation with thrips incidence, except rainfall $(r=0.54)$ which was nonsignificant. The multiple linear regression equation of pooled data $\mathrm{Y}=-5.061+0.124 \mathrm{X}_{1}$ $+0.099 \mathrm{X}_{2}-0.0427 \mathrm{X}_{3}+0.015 \mathrm{X}_{4}+0.009 \mathrm{X}_{5}+$ $0.050 \mathrm{X}_{6}$ indicated one unit increase in morning relative humidity caused increase thrips population by 0.0427 . However, a unit increase in maximum temperature, minimum temperature, evening relative humidity, rainfall and wind velocity caused decrease in their population by $0.124,0.099,0.015,0.009$ and 0.050 units. The weather factors collectively influenced the population of thrips to the extent of 96.1 per cent (Table 5).

\section{Spilarctia obliqua (Walker)}

The incidence appeared from $39^{\text {th }}$ SMW (4.00/plant) to attain a peak of 50.80 per plant $\left(42^{\text {nd }} \mathrm{SMW}\right)$ and died down later to reach nil at $46^{\text {th }}$ SMW during 2015. Similarly, the pest appeared at $40^{\text {th }}$ SMW (18.00/plant) and attained a peak of 48.80 per plant $\left(42^{\text {nd }} \mathrm{SMW}\right.$ ) and decreased later to reach 0.20 per plant at $45^{\text {th }}$ SMW. However, pooled data indicated the maximum incidence of 49.80 per plant during $42^{\text {nd }}$ SMW (Table 3). The correlation between the population of $S$. obliqua with all the weather parameters was found to be nonsignificant during both the seasons (2015 \& 2016) (Table 4). The multiple linear regression analysis indicates that all the weather factors put together influence the $S$. obliqua incidence to an extent of 78.9 and 66.0 per cent respectively in 2015 and 2016. The pooled analysis too indicated nonsignificant correlation with weather parameters. The multiple linear regression equation of pooled data $\mathrm{Y}=340.650$ $15.549 X_{1}+10.563 X_{2}+2.543 X_{3}-3.622 X_{4}-$ $0.033 \mathrm{X}_{5}-1.682 \mathrm{X}_{6}$ indicated one unit increase in maximum temperature, evening relative humidity, rainfall and wind velocity caused increase $S$. obliqua larval population by $15.549,3.622,0.033$ and 1.682 units. 
Table.1 List of defoliators and sucking pests which were recorded during the study period

\begin{tabular}{|l|}
\hline Pests \\
\hline Sucking pests \\
\hline Leaf hopper \\
\hline Whitefly \\
\hline Thrips \\
\hline Mealy bug \\
\hline Green stink bug \\
\hline Defoliators \\
\hline Tobacco Caterpillar \\
\hline Semiloopers \\
\hline Bihar hairy \\
\hline Caterpillar \\
\hline Tea caterpillar \\
\hline Safflower caterpillar \\
\hline Lymentrid \\
caterpillar \\
\hline Beet armyworm \\
\hline Ash Weevils \\
\hline Grasshoppers \\
\hline
\end{tabular}

\begin{tabular}{|c|c|}
\hline Scientific name & Taxonomic position \\
\hline $\begin{array}{l}\text { Amrasca biguttula biguttula } \\
\text { (Ishida) }\end{array}$ & (Homoptera : Cicadellidae) \\
\hline Bamisia tabaci (Gennadius) & (Homoptera : Aleyrodidae) \\
\hline $\begin{array}{l}\text { Thrips palmi (Karny) } \\
\text { Frankliniella schultzei (Tryb.) } \\
\text { Microcephalothrips abdominalis } \\
\text { (Crawford) }\end{array}$ & (Thysanoptera: Thripidae) \\
\hline Phenacoccus solenopsis (Tinsley) & (Hemiptera: Pseudococcidae) \\
\hline Nezara viridula (Linnaeus) & Pentatomidae: Heteroptera \\
\hline Spodoptera litura (Fab.) & (Lepidoptera : Noctuidae) \\
\hline $\begin{array}{l}\text { Thysanoplusia orichalcea (Fab.) } \\
\text { Trichoplusia ni (Hub.) }\end{array}$ & (Lepidoptera : Noctuidae) \\
\hline Spilarctia obliqua (Walker) & (Lepidoptera : Arctiidae) \\
\hline Dasychira sp.(Hub.) & (Lepidoptera : Lymantridae) \\
\hline Condica illecta (Walker) & (Lepidoptera : Noctuidae) \\
\hline Euproctis sp. & (Lepidoptera: Lymentridae) \\
\hline Spodoptera exigua (Hub.) & (Lepidoptera : Noctuidae) \\
\hline Myllocerus spp. & (Coleoptera : Curculionidae) \\
\hline Unidentified & (Orthoptera : Acrididae) \\
\hline
\end{tabular}

Table.2 Natural enemies of insect peston sunflowerrecorded during the study period

\begin{tabular}{l|}
\hline Natural enemy \\
\hline Lady bird beetle \\
Cheilomenes sexmaculata (Fab.) \\
Coccinella transversalis (Fab.) \\
\hline Green lace Wing Chrysoperla \\
zastrowi sillemi (Steph.) \\
\hline Brown lace wing \\
\hline Predatory bug \\
Eocanthecona furcellata (Wolfi) \\
\hline Spider (Unidentified species) \\
\hline Assassin bugs (Unidentified species) \\
\hline Nesidiocoris tenius(Reuter) \\
\hline Cyrtorhinus lividipennis (Reuter) \\
\hline Preying mantid \\
\hline
\end{tabular}

\begin{tabular}{|l|l|}
\hline Taxonomic position & Stages of defoliator pest \\
\hline Coleoptera : Coccinellidae & General predator \\
\hline Neuroptera : Chrysopidae & General predator \\
\hline $\begin{array}{l}\text { Neuroptera :Hemerobiidae } \\
\text { Hemiptera: Pentatomidae }\end{array}$ & General predator \\
\hline $\begin{array}{l}\text { Araneae } \\
\text { Hemiptera: Reduviidae }\end{array}$ & Lepidopteron larva \\
\hline Hemiptera: Miridae & Lepidopteron larva \\
\hline Hemiptera: Miridae & Sucking pest (white fly, Thrips) \\
\hline Mantodea & Sucking pest (Leafhoppers) \\
\hline
\end{tabular}


Table.3 Incidence of insect pests and natural enemies on sunflower at MARS, UAS, Dharwad (rabi: 2014-15, rabi: 2016-17)

\begin{tabular}{|c|c|c|c|c|c|c|c|c|c|c|c|c|c|c|c|c|c|c|}
\hline \multirow[t]{2}{*}{ SMW } & \multicolumn{6}{|c|}{2015} & \multicolumn{6}{|c|}{2016} & \multicolumn{6}{|c|}{ Pooled } \\
\hline & 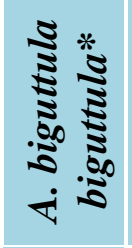 & 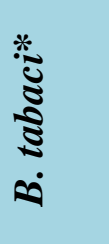 & $\stackrel{*}{\mathscr{n}}$ & 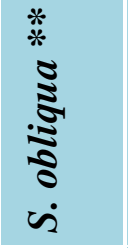 & 蒡 & 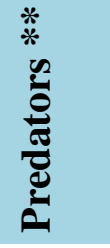 & 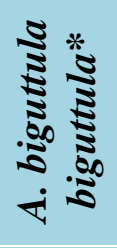 & 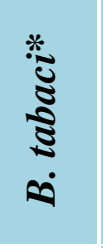 & $\stackrel{*}{\mathscr{E}}$ & 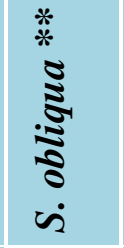 & 蒡 & 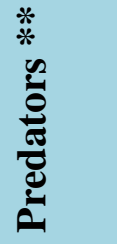 & 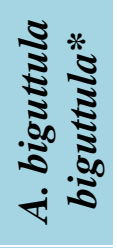 & 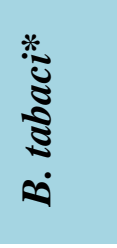 & $\stackrel{*}{\mathscr{*}}$ & 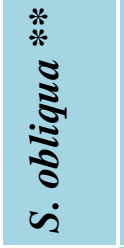 & 葛 & 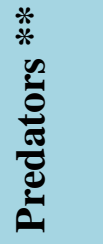 \\
\hline 37 & 2.00 & 1.40 & 0.60 & 0.00 & 0.20 & 0.30 & 0.50 & 0.50 & 0.70 & 0.00 & 0.20 & 0.10 & 1.25 & 0.95 & 0.65 & 0.00 & 0.20 & 0.20 \\
\hline 38 & 5.80 & 0.70 & 1.00 & 0.00 & 0.20 & 0.40 & 0.30 & 0.30 & 1.20 & 0.00 & 0.20 & 0.40 & 3.05 & 0.50 & 1.10 & 0.00 & 0.20 & 0.40 \\
\hline 39 & 7.80 & 0.80 & 0.30 & 4.00 & 0.20 & 0.50 & 0.40 & 0.50 & 1.40 & 0.00 & 0.60 & 0.50 & 4.10 & 0.65 & 0.85 & 2.00 & 0.40 & 0.50 \\
\hline 40 & 7.60 & 0.50 & 0.30 & 2.50 & 0.50 & 0.50 & 0.60 & 0.30 & 1.90 & 18.00 & 0.80 & 0.60 & 4.10 & 0.40 & 1.10 & 10.25 & 0.65 & 0.55 \\
\hline 41 & 11.40 & 0.90 & 0.20 & 33.50 & 0.40 & 0.50 & 0.50 & 0.60 & 0.30 & 37.50 & 1.00 & 0.50 & 5.95 & 0.75 & 0.25 & 35.50 & 0.70 & 0.50 \\
\hline 42 & 20.80 & 0.80 & 0.00 & 50.80 & 0.30 & 0.80 & 1.00 & 1.70 & 0.00 & 48.80 & 0.80 & 0.60 & 10.9 & 1.25 & 0.00 & 49.80 & 0.55 & 0.70 \\
\hline 43 & 22.30 & 0.70 & 0.00 & 15.00 & 0.20 & 0.40 & 2.20 & 2.60 & 0.00 & 29.50 & 0.70 & 0.50 & 12.25 & 1.65 & 0.00 & 22.25 & 0.45 & 0.45 \\
\hline 44 & 21.00 & 0.60 & 0.00 & 3.00 & 0.10 & 0.10 & 2.60 & 1.50 & 0.00 & 3.20 & 0.30 & 0.40 & 11.8 & 1.05 & 0.00 & 3.10 & 0.20 & 0.25 \\
\hline 45 & 21.00 & 0.50 & 0.00 & 0.50 & 0.00 & 0.10 & 3.50 & 0.00 & 0.00 & 0.20 & 0.10 & 0.40 & 12.25 & 0.25 & 0.00 & 0.35 & 0.05 & 0.25 \\
\hline 46 & 18.50 & 0.50 & 0.00 & 0.00 & 0.00 & 0.40 & 8.70 & 0.00 & 0.00 & 0.40 & 0.00 & 0.30 & 13.6 & 0.25 & 0.00 & 0.20 & 0.00 & 0.35 \\
\hline
\end{tabular}


Table.4 Correlation between sunflower insectpest population and weather parameters (rabi 2015 \& 2016)

\begin{tabular}{|c|c|c|c|c|c|c|c|c|c|c|c|c|c|c|c|c|c|c|}
\hline \multirow[t]{2}{*}{ Pests } & \multicolumn{6}{|c|}{ Temperature $\left({ }^{\circ} \mathrm{C}\right)$} & \multicolumn{6}{|c|}{ Relative humidity (\%) } & \multicolumn{3}{|c|}{ Rainfall (mm) } & \multicolumn{3}{|c|}{$\begin{array}{c}\text { Wind velocity } \\
\text { (kmph) }\end{array}$} \\
\hline & $\begin{array}{l}\text { Max. } \\
2015\end{array}$ & $\begin{array}{l}\text { Max. } \\
2016\end{array}$ & Pooled & $\begin{array}{l}\text { Min. } \\
2015\end{array}$ & $\begin{array}{l}\text { Min. } \\
2016\end{array}$ & Pooled & $\begin{array}{c}\text { Morn. } \\
2015\end{array}$ & $\begin{array}{c}\text { Morn. } \\
2016\end{array}$ & Pooled & $\begin{array}{l}\text { Even. } \\
2015\end{array}$ & $\begin{array}{l}\text { Even. } \\
2016\end{array}$ & Pooled & 2015 & 2016 & Pooled & 2015 & 2016 & Pooled \\
\hline $\begin{array}{l}\text { A. biguttula } \\
\text { biguttula }\end{array}$ & $0.65^{*}$ & 0.59 & $0.83^{* *}$ & $-0.81^{* *}$ & -0.50 & $-0.85^{* *}$ & $-0.77^{* *}$ & -0.60 & $-0.91^{* *}$ & $-0.74^{*}$ & -0.57 & $-0.89^{* *}$ & -0.29 & -0.34 & -0.37 & $-0.68^{*}$ & -0.62 & $-0.85^{* *}$ \\
\hline B. tabaci & -0.25 & 0.56 & 0.48 & 0.62 & 0.05 & 0.13 & 0.22 & -0.20 & -0.30 & 0.317 & -0.43 & -0.38 & -0.28 & -0.34 & -0.30 & 0.35 & -0.41 & -0.36 \\
\hline Thrips & $-0.79^{* *}$ & $-0.81^{* *}$ & $-0.83^{* *}$ & $0.66^{*}$ & 0.58 & $0.70^{*}$ & 0.60 & $0.77^{* *}$ & $0.85^{* *}$ & 0.62 & $0.85^{* *}$ & $0.86^{* *}$ & 0.06 & 0.58 & 0.54 & $0.80^{* *}$ & $0.83^{* *}$ & $0.86^{* *}$ \\
\hline S. obliqua & 0.46 & 0.32 & 0.43 & -0.01 & 0.11 & -0.02 & -0.47 & -0.01 & -0.26 & -0.56 & -0.29 & -0.44 & -0.15 & 0.21 & 0.01 & -0.54 & -0.31 & -0.46 \\
\hline
\end{tabular}

*Correlation significant at the 0.05 level

**Correlation significant at the 0.01 level

Table.5 Regression equation for sunflower insect pest population and weather parameters (Pooled rabi 2015 \& rabi 2016)

\begin{tabular}{|l|l|l|l|}
\multicolumn{1}{c|}{ Pest } & \multicolumn{1}{|c|}{ Regression equation } & $\begin{array}{c}\mathbf{R}^{2} \text { value } \\
(\%)\end{array}$ \\
\hline A. biguttula biguttula & $\mathrm{Y}=-2.816+1.355 \mathrm{X}_{1}-1.487 \mathrm{X}_{2}-0.037 \mathrm{X}_{3}+0.082 \mathrm{X}_{4}-0.011 \mathrm{X}_{5}-0.057 \mathrm{X}_{6}$ & 92.0 \\
\hline B. tabaci & $\mathrm{Y}=-2.199-0.025 \mathrm{X}_{1}+0.487 \mathrm{X}_{2}-0.057 \mathrm{X}_{3}-0.030 \mathrm{X}_{4}+0.002 \mathrm{X}_{5}+0.014 \mathrm{X}_{6}$ & 88.6 \\
\hline Thrips & $\mathrm{Y}=-5.061+0.124 \mathrm{X}_{1}+0.099 \mathrm{X}_{2}-0.0427 \mathrm{X}_{3}+0.015 \mathrm{X}_{4}+0.009 \mathrm{X}_{5}+0.050 \mathrm{X}_{6}$ & 96.1 \\
\hline S. obliqua & $\mathrm{Y}=340.650-15.549 \mathrm{X}_{1}+10.563 \mathrm{X}_{2}+2.543 \mathrm{X}_{3}-3.622 \mathrm{X}_{4}-0.033 \mathrm{X}_{5}-1.682 \mathrm{X}_{6}$ & 89.0 \\
\hline
\end{tabular}

$\mathrm{X}_{1}=$ Maximum temperature $\left({ }^{\circ} \mathrm{C}\right)$

$\mathrm{X}_{2}=$ Minimum temperature $\left({ }^{\circ} \mathrm{C}\right)$

$\mathrm{X}_{3}=$ Morning Relative humidity $(\%)$

$\mathrm{X}_{4}=$ Evening Relative humidity (\%)

$\mathrm{X}_{5}=$ Rain fall $(\mathrm{mm})$

$\mathrm{X}_{6}=$ Wind velocity $(\mathrm{kmph})$ 
However, a unit increase in minimum temperature and morning relative humidity caused decrease in their population by 10.563 and 2.543 units. The regression analysis indicates that all the weather factors collectively influenced the population of $S$. obliqua to the extent of 89.0 per cent (Table 5).

Singh and Singh (1993) reported the peak population of $S$. obliqua on sunflower $(\mathrm{Cv}$. MSFH-8) at Ludhiana, Punjab when the average temperature and $\mathrm{RH}$ were $30.6^{\circ} \mathrm{C}$ and 48.8 per cent, respectively. According to Thakur and Kaistha (1994) in Himachal Pradesh the pest incidence was higher when mean temperatures was ranging $23.1-33.4^{\circ} \mathrm{C}$ with $71 \%$ RH. Sharma et al., (1997) correlated weather parameters (Temperature, rainfall and sunshine hours) with S. obliqua larval population in soybean and the result was insignificant.

Whereas, Bilapate and Chakravarthy (1999) who reported the defoliators, $S$. litura and $S$. obliqua on sunflower appeared in September at Bengaluru, whereas, at Hyderabad their infestation was high in November. Kakakhel et al., (2000) recorded the maximum population of hairy caterpillar (D. obliqua), in the second week of October on sunflower crop. Patel (2015) reported S. obliqua larval population on caster had a significant positive correlation with the maximum temperature and non-significant correlation with other weather parameters. Lodaya (2016) reported significant positive correlation with wind velocity and it was non-significant with all other weather parameters such as mean temperature, wind velocity, relative humidity and rainfall on soybean crop. Syed Muzammiland Biradar (2017) reported the incidence of defoliators in sunflower at Vijayapura. The population density of $S$. obliqua was maximum during 73 DAS $\left(2^{\text {nd }}\right.$ fortnight of November).
The above findings reported the peak activity of hairy caterpillar, S. obliqua during different part of the year in different geographical region. Further, their relation with weather parameters also varied a lot without a definite pattern. It appears that hairy caterpillar survive well under wide environmental conditions and weather factors.

\section{Other defoliators}

The other defoliators include $S$. litura, $D$. mendosa and C. Illecta. Their incidence was observed with varying intensity, which ranging from 0.00 to 0.50 and 0.00 to 1.00 per plant in 2015 and 2016, respectively. The incidence of other defoliators were little more at $40^{\text {th }}$ and $41^{\text {st }}$ SMW of 2015 and 2016, respectively (Table 3 ).

\section{Predators}

The incidence of different predators occurring in sunflower ecosystem viz., spiders, wasps, coccinelids, green lacewing, pentatomid predatory bug and others were recorded during the course of this investigation. The predators population was prevailed throughout the cropping period during both the seasons. The incidence was observed with varying intensity ranging from 0.10 to 0.80 per plant and 0.10 to 0.60 per plant in 2015 and 2016, respectively. In 2015, highest incidence recorded in $42^{\text {nd }}$ SMW was 0.80 per plant and later their population decreased (0.10/ plant at 44 and $45^{\text {th }}$ SMW) to increase in $46^{\text {th }} \mathrm{SMW}$ (0.30/ plant). In 2016, maximum incidence recorded was 0.60 per plant during $40^{\text {th }}$ SMW and later their population decreased $\left(0.50 /\right.$ plant at $41^{\text {st }}$ SMW) to increase 0.60 per plant at $42^{\text {nd }}$ SMW and later died down to reach 0.30 per plant by the end of the season ( $46^{\text {th }}$ SMW) (Table 3).

Basappa (2011) reported several general predators in sunflower such as, spiders, 
Chrysoperla, predatory bugs, insectivorus birds etc. play an important role in the suppression of insect pest. Syed Muzammiland Biradar (2017) reported highest coccinellids and spiders population on 73 days old sunflower crop.

The earlier findings are in line with the present investigation with respect to diversity of the predatory species in sunflower ecosystem and also their peak activity. The present results showed when pest population was maximum, the predatory population was also maximum and this clearly indicates numerical response of the natural enemies.

\section{References}

Anonymous, 2002, Annual Progress Report of AICRP on Oilseeds (Sunflower), Directorate of Oilseeds Research, ICAR, Hyderabad, p. 234.

Basappa, H., 2011, Biodiversity of biocontrol agents in sunflower ecosystem. J. Biol. Control, 25 (3): 182-192.

Bilapate, G. G. and Chakravarthy, A. K., 1999, Bio-ecology of sunflower pests and their management. In: IPM systems in Agriculture (Eds. R. K. Upadhyay, K. G. Mukerji and R. L. Rajak), 5: 319347.

Kakakhel, S. A., Islam, N., Amjad M. and Malik, M. A., 2000, Insect pests complex of sunflower (Helianthus annuus). Pakistan J. Biol. Sci., 3(4): 669-671.

Lodaya, J. P., 2016, Succession and management of major insect pests of soybean, Glycine max L. (Merrill). Ph.
D. thesis, Anand agricultural University. pp. 1-234.

Meenakshi, J., 2006, Studies on the insect pest complex of sunflower (Helianthus annuus L.) with special reference to thrips. M.Sc. Thesis, University of Agricultural Sciences, Bangalore, India, p. 83.

Men, V. B., Saznaik, D. N., Peshkar, L. N., Deshmukh, D. and Kolhe, R. V., 1996, Effect of weather factors on the population of sunflower jassids. $P K V$ Research Journal, 20 (2): 151-154.

Patel, R. J., 2015, Biology, population dynamics and management of bihar hairy caterpillar, Spilarctia obliqua Walker on castor. M.Sc. Thesis, Anand Agricultural University, Anand, Gujarat, India. pp. 1-118.

Sharma, D., Bagmare, A. and Gupta, A., 1997, Effect of weather parameters on population build-up of key pests of soybean. J. Insect Sci., 10 (2): 12-124.

Singh, I. and Singh, G., 1993, Seasonal incidence of Spilosomaobliqua Walker on sunflower in Punjab. J. Res. Punjab Agric. Univ., 30 (3/4): 164-167.

Syed Muzammiland Biradar, A. P., 2017, Survey and surveillance of sunflower defoliator pests and their natural enemies in Northern dry zone of Karnataka. Int. J. Plant. Protec., 10 (1): 69-74.

Thakur, A. K. and Kaistha, S., 1994, Incidence of insect pests in sesame (Sesamum indicum Linn.) under rainfed conditions in Paonta valley of Himachal Pradesh. Pest Management and Economic Zoology. 2 (2): 159-161.

\section{How to cite this article:}

Geetha, S. and Hegde, M.G. 2018. Incidence of Insect Pests and Natural Enemies in Sunflower Crop Ecosystem. Int.J.Curr.Microbiol.App.Sci. 7(09): 1593-1601.

doi: https://doi.org/10.20546/ijcmas.2018.709.191 